\title{
Relationship between functional constipation and anal-retentive behavior features
}

\author{
Tonguç Utku Yılmaz ${ }^{* 1}$, Halil İbrahim Taş ${ }^{* 2}$, Ezgi Uçarr ${ }^{1}$, Cem Cerit ${ }^{3}$, Altay Çelebi ${ }^{4}$, Sertaç Ata Güler ${ }^{1}$, Zafer Utkan ${ }^{1}$ \\ ${ }^{1}$ Department of General Surgery, Kocaeli University School of Medicine, Kocaeli, Turkey \\ ${ }^{2}$ Department of Psychiatry, Çanakkale 18 Mart University School of Medicine, Çanakkale, Turkey \\ ${ }^{3}$ Department of Psychiatry, Kocaeli University School of Medicine, Kocaeli, Turkey \\ ${ }^{4}$ Division of Gastroenterology, Kocaeli University School of Medicine, Kocaeli, Turkey \\ ${ }^{*}$ Equally Contributed
}

\# This study was presented at the $20^{\text {th }}$ National Congress of Surgery, 13-17 April 2016, Antalya, Turkey.

\begin{abstract}
Objective: Constipation is the most commonly seen defecation problem related to several environmental factors. Defecation is learned in the childhood anal period in which anal characteristic features appear. Problems in the childhood anal period may affect not only characters but also defecation function. This study aimed to evaluate the relationship between constipation and anal characteristic features of participants with functional constipation.

Material and Methods: Patients with functional constipation were included into the study according to the ROME III criteria. Patients with irritable bowel disease, slow transit constipation, outlet obstruction constipation, malignancy, and psychiatric diseases were excluded from the study. Patients filled out Personality Belief Questionnaire, Hospital Anxiety and Depression Scale, and Obsessive Belief Questionnaire. The results were compared with healthy individuals.
\end{abstract}

Results: A total of 47 patients with functional constipation were included in the study. Avoidant, obsessive-compulsive, antisocial, narcissistic, and paranoid personality traits were found to be higher in patients with constipation than in the control group. Perfectionism/certainty, importance and control, and hospital anxiety scores were found to be higher in patients with constipation than in the control group.

Conclusion: Constipation may be related to several factors, such as socioeconomic environment, emotional stress, age, and diet, among others. Here, it was found that anal-retentive behavior features are prominent in functional constipation. Biofeedback, which can be regarded as psychotherapy of defecation control, can be used for treatment.

Keywords: Anal-retentive, biofeedback, constipation, childhood, personality disorders

Cite this article as: Yılmaz TU, Taş Hi, Uçar E, Cerit C, Çelebi A, Güler SA, Utkan Z. Relationship between functional constipation and anal-retentive behavior features. Turk J Surg 2019; 35 (3): 165-170

Corresponding Author

Tonguç Utku Yılmaz

E-mail: tonyutku@hotmail.com

Received: 23.11.2017

Accepted: 19.03.2018

Available Online Date: 21.09.2018

o Copyright 2019 by Turkish Surgical Society Available online at www.turkjsurg.com

DOI: $10.5578 /$ turkjsurg. 4035

\section{INTRODUCTION}

Defecation is a complex mechanism composed of sympathetic and parasympathetic systems, sacral spinal cord reflexes, normal anorectal sensation, and voluntary control of the external sphincters (1). Impairments of this process are called defecation disorders and generally associated with constipation. The term "Functional Defecation Disorders (FDDs)" has been preferred to describe constipation associated with anorectal dysfunction, according to recent consensus (ROME III) (2). Constipation is the etiology of most benign anorectal diseases, such as hemorrhoid and chronic anal fissure. Although anatomical and functional factors related with senility and sex have been addressed for etiology, constipation is also a common problem in children (3-5).

In addition to anatomical factors, psychological factors also play a role $(6,7)$. Anal stage is defined as the period of controlling defecation in children. In this period, children learn how to hold their stool and defecate. Children understand the important part of defecation (i.e., voluntary control of the sphincter) during this period. Defecation control is the interaction, communication, and exertion of power by children against their environment. Children experience several conflicts in this period. These conflicts may lead to anal-retentive personality, which includes willfulness, stinginess, excessive thoroughness, and excessive tidiness $(7,8)$. Early toilet training, excessive parent-child conflict, irrational fears, and anxieties around toileting can also lead to constipation in children (9). 
This study sought to evaluate the possible existence of anal-retentive personality features in patients with FDD.

\section{MATERIAL and METHODS}

This retrospective descriptive study was performed at the Department of General Surgery, Kocaeli University. The local ethics committee of Kocaeli University (KOÜKAEK 2015/49) approved the study. Inclusion criteria to the study was being diagnosed with FDD according to the ROME III criteria at the Department of Gastroenterology and referred to the general surgery outpatient clinic between February 2015 and March 2016 (2,10). Gastroenterology reports were reviewed to ascertain whether or not patients had been evaluated by anal manometry and colon transit time measurement in order to rule out slow transit constipation and outlet dysfunction. Patients who had previously known psychiatric, oncologic, inflammatory, and neurological diseases were excluded from the study. Patients admitted to the general surgery outpatient department were examined for hemorrhoid or anal fissure related with constipation. Chronic anal fissure is diagnosed as fissure in the anal canal present for $\geq 3$ months and is indurated, fibrotic, has anal skin tags, and is located in the midline. Patients who had previously undergone surgical treatment for hemorrhoids or anal fissure were not included in the study. Patients with constipation were divided into two groups: those with (i.e., constipation with disease) and those without benign anorectal disease (i.e., constipation without disease). The control group was composed of healthy individuals with no previous gastrointestinal or psychiatric diseases. Demographic data included age, sex, body weight, and height. Informed consent was obtained from all of the participants of the study.

\section{Personality Belief Questionnaire-Short Form}

Personality Belief Questionnaire-Short Form (PBQ-SF; Turkish version) is composed of questions that query an individual's basic beliefs about himself, other people, and the world (10). In its initial configuration, PBQ has several questions assessing each personality disorder found in the Diagnostic and Statistical Manual of Mental Disorders (DSM) (i.e., avoidant, dependent, passive-aggressive, obsessive-compulsive, antisocial, narcissistic, histrionic, paranoid, schizoid/schizotypal, and borderline). In each question, participants scored the statement from 0 to 4 ac- cording to their beliefs. Validity and reliability of the Turkish version of the questionnaire were performed by Taymur et al. (11).

\section{Hospital Anxiety and Depression Scale}

Hospital Anxiety and Depression (HAD) is composed of 14 questions that evaluate depression and anxiety of the participant. The aim of the scale is not to diagnose but instead to define the risk groups for anxiety and depression. HAD was developed by Zigmoid et al., and the validity and reliability were evaluated (12). Validity and reliability of the Turkish version of the questionnaire were performed by Aydemir (13).

\section{Obsessive Beliefs Questionnaire}

Obsessive Beliefs Questionnaire (OBQ) was developed by the Obsessive-Compulsive Cognitions Working Group and is composed of 44 questions scored on a 7-point Likert scale (14). The subgroups of $\mathrm{OBQ}$ include Responsibility/Threat Estimation, Perfectionism/Certainty, and Importance and Control Thoughts. Validity and reliability of the Turkish version of the questionnaire were performed by Boysan et al. (15).

\section{Statistical Analysis}

All statistical analyses were performed using the Statistical Package for the Social Sciences version 17.0 (SPSS; IBM Corp., CA, USA). A p-value $<0.05$ was accepted as statistically significant. Data were expressed as mean $\pm \mathrm{SD}$. Distribution of parametric data was evaluated by Kolmogorov-Smirnov test. Statistical data of the three groups with normal distribution were compared with the ANOVA post hoc Tukey test. Kruskal-Wallis test was used for the comparison of data with non-normal distribution. Categorical comparison was performed by Chi-square test. Subgroup comparisons of $\mathrm{OBQ}$ were performed by Mann-Whitney $U$ test.

\section{RESULTS}

During a 12-month period, a total of 47 patients with FDD were included into the study. A total of 23 individuals were included into the study as the control group. Table 1 shows the demographic results. There is no statistical difference between the groups by age, sex, weight, and height.

Table 2 shows OBQ and HAD scale results. There is no statistical difference between the groups for the HAD depression scale and

Table 1. Demographics of the patients

\begin{tabular}{|l|c|c|c|c|}
\hline & $\begin{array}{c}\text { Constipation with disease } \\
(\mathbf{n = 3 1 )}\end{array}$ & $\begin{array}{c}\text { Constipation without disease } \\
(\mathbf{n = 1 6 )}\end{array}$ & $\begin{array}{c}\text { Control } \\
(\mathbf{n = 1 6 )}\end{array}$ & $10 / 13$ \\
\hline Sex (male/female) & $12 / 19$ & $11 / 5$ & $44.3 \pm 10.3$ & 0.135 \\
\hline Age (years) & $39.3 \pm 13.8$ & $37.4 \pm 13.2$ & $167.8 \pm 10.5$ & 0.197 \\
\hline Height (cm) & $164.1 \pm 17.8$ & $169.5 \pm 8.2$ & $80.7 \pm 19.7$ & 0.396 \\
\hline Weight (kg) & $72.6 \pm 16.2$ & $72.0 \pm 14.3$ & 0.169 \\
\hline * ANOVA is used for comparison of the mean age, height and weight of the groups. Kruskal-Wallis is used to compare the ratio of sexes between groups. \\
\hline
\end{tabular}


Table 2. Comparison of obsessive beliefs, anxiety and depression among the study groups

\begin{tabular}{|c|c|c|c|c|}
\hline & $\begin{array}{l}\text { Constipation with disease } \\
\qquad(n=31)\end{array}$ & $\begin{array}{l}\text { Constipation without disease } \\
\qquad(n=16)\end{array}$ & $\begin{array}{l}\text { Control } \\
(n=23)\end{array}$ & $\mathrm{p}$ \\
\hline $\begin{array}{l}\text { OBQ } \\
\text { (responsibility/threat estimation) }\end{array}$ & $58.6 \pm 14.4$ & $65.2 \pm 17.9$ & $54.0 \pm 18.6$ & 0.131 \\
\hline $\begin{array}{l}\text { OBQ } \\
\text { (perfectionism/certainty) }\end{array}$ & $62.7 \pm 16.7^{a}$ & $65.0 \pm 20.4^{\beta}$ & $51.0 \pm 20.5$ & $\begin{array}{c}\mathbf{0 . 0 2} \\
{ }^{a} p=0.037,{ }^{\beta} p=0.009\end{array}$ \\
\hline $\begin{array}{l}\text { OBQ } \\
\text { (importance and control thoughts) }\end{array}$ & $39.6 \pm 12.7^{a}$ & $38.5 \pm 11.2^{\beta}$ & $31.4 \pm 11.8$ & $\begin{array}{c}0.036(0.018-0.04-0.893) \\
{ }^{a} p=0.004,{ }^{\beta} p=0.018\end{array}$ \\
\hline HAD depression scale & $7.0 \pm 3.5$ & $7.4 \pm 4.9$ & $5.0 \pm 3.7$ & 0.108 \\
\hline HAD anxiety scale & $8.6 \pm 4.9^{a}$ & $7.3 \pm 5.1^{\beta}$ & $5.4 \pm 2.7$ & $\begin{array}{c}0.016(0.014-0.677-0.217) \\
{ }^{a} p=0.014,{ }^{\beta} p=0.67\end{array}$ \\
\hline
\end{tabular}

the OBQ Responsibility/Threat estimation subgroups ( $p=0.108$ and $p=0.131$, respectively). The Perfectionism/Certainty score of the patients with constipation with disease and without disease was significantly higher than that of the control group $(p=0.037$ and $p=0.009$, respectively). There were no significant differences between the patients with constipation with and without disease $(p=0.479)$. The Importance and Control Thoughts score of the patients with constipation with and without disease was significantly higher than that of the control group ( $p=0.018$ and $p=0.04$, respectively). There were no significant differences between the patients with constipation with and without disease $(p=0.893)$. HAD score was significantly higher in patients with constipation with disease than in the control group $(p=0.014)$. However, the difference in anxiety scores between the patients with constipation without disease and the control group was not significant $(p=0.217)$.

Table 3 shows PBQ-SF subgroup comparisons between the groups. The obsessive-compulsive type beliefs were more common in patients with constipation with and without disease than in the control group ( $p=0.028)$. Avoidant and narcissistic beliefs were more common in patients with constipation with disease than in the control group. Antisocial and paranoid beliefs were more common in patients with constipation with disease than in the control group.

Table 3. Comparison of personality beliefs among the study groups

\begin{tabular}{|c|c|c|c|c|}
\hline $\begin{array}{l}\text { Personality belief questionnaire } \\
\text { (PBQ), subgroups }\end{array}$ & $\begin{array}{l}\text { Constipation with disease } \\
\qquad(n=31)\end{array}$ & $\begin{array}{l}\text { Constipation without disease } \\
\qquad(n=16)\end{array}$ & $\begin{array}{l}\text { Control } \\
(n=23)\end{array}$ & $\mathbf{p}$ \\
\hline Avoidant* & $13.8 \pm 5.7^{a}$ & $12.1 \pm 3.8$ & $10.0 \pm 5.0$ & $\mathbf{0 . 0 2 9}\left({ }^{a} p=0.022\right)$ \\
\hline Dependent* & $8.8 \pm 5.7$ & $9.1 \pm 5.4$ & $6.4 \pm 4.0$ & 0.176 \\
\hline Passive-aggressive* & $12.6 \pm 4.7$ & $12.1 \pm 3.8$ & $11.4 \pm 6.1$ & 0.720 \\
\hline Obsessive-compulsive* & $15.4 \pm 4.5^{a}$ & $15.6 \pm 5.4^{\beta}$ & $8.0 \pm 4.4$ & $\begin{array}{c}<0.001 \\
\left({ }^{a} p<0.001,{ }^{\beta} p<0.001\right)\end{array}$ \\
\hline Antisocial** & $10.9 \pm 6.0^{a}$ & $9.0 \pm 4.3$ & $6.4 \pm 4.9$ & $\mathbf{0 . 0 1 9}\left({ }^{a} p=0.008\right)$ \\
\hline Narcissistic* & $10.1 \pm 5.6^{a}$ & $9.6 \pm 4.3$ & $6.7 \pm 3.5$ & $0.03\left({ }^{a} p=0.028\right)$ \\
\hline Histrionic* & $8.1 \pm 6.1$ & $7.8 \pm 3.8$ & $5.3 \pm 3.8$ & 0.112 \\
\hline Schiizoid/schizotypal* & $12.7 \pm 6.3$ & $11.3 \pm 5.4$ & $9.4 \pm 6.7$ & 0.178 \\
\hline Paranoid** & $12.3 \pm 6.1^{a}$ & $7.8 \pm 3.3$ & $8.0 \pm 5.8$ & $\mathbf{0 . 0 1 1}\left({ }^{\mathrm{a}} \mathrm{p}=0.011\right)$ \\
\hline Borderline* & $9.5 \pm 6.3$ & $8.9 \pm 3.8$ & $6.5 \pm 3.9$ & 0.099 \\
\hline
\end{tabular}




\section{DISCUSSION}

Our study showed that anal-retentive characteristic features related to the period of defecation control are significantly higher in patients with constipation than in healthy people. Constipation is one of the most common gastrointestinal disorders seen by gastroenterologists and primary care physicians. The prevalence of the disease in adults older than 60 years of age is 33\%, whereas the overall prevalence among adults of all ages is approximately $16 \%$ (16). Constipation reduces quality of life and poses a large economic burden, with more than $\$ 820$ million spent on laxatives per year (17). Chronic constipation is defined as infrequent bowel movements and myriad symptoms (hard stool, straining, feeling of incomplete evacuation, sensation of fecal obstruction, and digitation for defecation) with less than three bowel movements per week for at least 3 of the prior 12 months. FDD includes primary constipation and has different features than slow transit constipation and obstructed constipation. In our study, FDD-related constipation is diagnosed using the ROME III criteria and excludes outlet dysfunction and slow transit constipation (10).

Our study showed that patients with constipation have much more anal-retentive behavior features than healthy subjects. Anal-retentive behavior features are developed during the anal stage of children between the ages of 1 and 3 years (18). Anal-retentive personality has an excessive amount of libido fixated on the pleasures discovered during the period of toilet training. Control of defecation is a kind of libido that leads to anal-retentive personality during the time when superego is formed (18). Freud suggested that children in the anal stage of development regard the release of their feces as a gift to the parent-a gift that can be given or withheld. Toilet withholding is the most common response seen in that period. Anal-retentive children hold their feces in a miserly fashion, releasing waste only when strongly encouraged or rewarded (19). These characteristics are supposedly present in anally fixated adults who demand that others offer them devotion and sacrifice. Anal-retentive adults hoard love and affection while commonly withholding their own affection from others. Another type of an anal-retentive person is an individual who seeks to obsessively control his or her environment and the people in his or her life, often by being stingy or miserly (19). Fixation at this stage can lead to a highly moralistic and overly controlled personality style.

It has been reported that voluntary holding in healthy people can remarkably delay defecation and, at the same time, slow transit through the ascending colon and rectosigmoid tract (20). This type of mechanism often produces constipation in children and can continue into adulthood as an acquired illness behavior (21). One-third of patients with functional constipation had reported constipation since childhood, whereas others developed constipation during adulthood (22). The onset of symptoms during childhood suggests that at least one-third of patients with func- tional constipation may have never learned the art of proper defecation or acquired faulty habits during toilet training (23). Early toilet training, excessive parent-child conflict, and irrational fears during the anal stage may result in functional constipation (9). In addition to these withholding features, psychosocial experiences, physiological functioning, or susceptibility to developing a functional gastrointestinal disorder, including functional constipation, is seen (24). It has been shown that physiological stress, anxiety, socioenvironmental factors, and genetic predisposition may also contribute to the development of constipation $(24,25)$. Psychological distress is associated with pelvic floor tension and increased extrinsic nerve supply and rectal mucosal blood flow to the gut (26). The mechanism in emotional stress and constipation result in the alteration of bowel habits via the brain-gut axis.

The prevalence of obsessive beliefs, such as Perfectionism/Certainty and Importance and Control Thoughts, in patients with constipation is significantly higher than that in healthy controls. Anxiety about making a mistake, precise and excessive desire to finish a task, strict and inflexible attitudes toward beliefs, and uncomfortable feelings about uncertain events are higher in patients with constipation. Higher rates of obsessive beliefs in patients with constipation demonstrate that these patients attach importance to compulsive thoughts, and that they need much more control for these thoughts (11). The desire to maintain control is a coping mechanism for individuals, and uncontrolled life events are predictive of psychological stress (24). Previous studies have shown a high prevalence of emotional distress including anxiety, depression, and social dysfunction in patients with functional constipation (24). In the present study, we did not only show high anxiety and social dysfunction rates but also found that other personality disorders are associated with anal characteristic features. It has been shown that stress may act via the enteric nervous system to inhibit colonic motility and thus prolong colonic transit (24). However, in our study, we included patients with normal transit time.

The Personality Belief Scale was prepared according to personality disorders in DSM IV (18). Avoidant, obsessive-compulsive, paranoid, antisocial, and narcissistic beliefs are more common in patients with constipation than in healthy subjects. The most significant difference between the constipated and control groups was obsessive beliefs. Obsessive personality features overlap with anal characteristic features. Individuals with anal characteristic features are rigorous, prim, perfectionist, extremely niggling, and dislike uncertainty. There is limited information about obsessive-compulsive disorder and obsessive-compulsive personality disorder among patients with constipation. Thus, we thought that the subject was worth investigating. The present study also found that paranoid personality including skeptical and insecure features and thoughts about the control of other people and the desire to find secret meanings in events was much more com- 
mon in patients with constipation with diseases. Furthermore, antisocial personality (including difficulty coping with societal rules and undeveloped superego) and narcissistic personality (including exaggerated appraisal of one's personal features) were much more common in patients with constipation with diseases. However, only obsessive-compulsive personality beliefs were significantly higher in both patients with constipation with and without disease. This shows that obsessive-compulsive features are important parts of anal-retentive behavior features. On the other hand, some features are more prominent in patients with constipation and disease than in patients with constipation only, which may be due to the severity of anal-retentive behavior features. Unfortunately, the limitation of the present study was that it was unable to describe the relationship between the severity of the disease and the anal-retentive behavior features. Anal characteristic features are not the disease to be treated, but when personality disorders are observed, first line of therapy may be psychotherapy.

Biofeedback is a learning strategy derived from psychological learning theory (27). The basis of the use of this treatment is feedback signals from various autonomic systems that shape the behavior of the organ in a desired direction. Biofeedback is used for several gastrointestinal diseases including constipation, incontinence, and gastric motility, among others. Biofeedback treatment in constipation is much more effective for improving muscle coordination control than for treating slow transit time constipation (27). Taken together, biofeedback can be regarded as a kind of psychotherapy for defecation control. Patients with functional constipation and anal characteristic features may benefit from both biofeedback and psychotherapy.

\section{CONCLUSION}

Anal-retentive behavior features are more prominent in patients with constipation. Anal-retentive behavior features are developed during the anal period in which defecation is learned, and there might be a relationship between these two entities. Biofeedback treatment is one of the modalities for both anal-retentive behavior features and functional constipation.

Ethics Committee Approval: Ethics committee approval was received for this study from the Ethics Committee of Kocaeli University School of Medicine.

Informed Consent: Written informed consent was obtained from patients who participated in this study.

Peer-review: Externally peer-reviewed.

Author Contributions: Concept - T.U.Y., H.I.T.; Design - T.U.Y., H.I.T.; Supervision - Z.U., A.Ç.; Resource - E.U., C.C., S.A.G.; Materials - T.U.Y., E.U., S.A.G., C.C.; Data Collection and/or Processing - H.I.T., E.U., C.C., A.C.; Analysis and/or Interpretation - T.U.Y., C.C., Z.U.; Literature Search - H.I.T., S.A.G., E.U.; Writing Manuscript - T.U.Y., H.I.T.; Critical Reviews - Z.U., A.Ç.
Conflict of Interest: The authors have no conflicts of interest to declare.

Financial Disclosure: The authors declared that this study has recieved no financial support.

\section{REFERENCES}

1. Skandalakis JE, Kingsnorth AN. Large intestine and anorectum. Mechanism of defecation. In: Skandalakis JE, Kingsnorth AN (eds). Surgical Anatomy. Paschalidis Medical Publication, 2004: 861-1000.

2. Bharucha $A E$, Wald $A$, Enck $P$, Rao S. Functional anorectal disorders. Gastroenterology 2006; 130: 1510-8. [CrossRef]

3. Akervall S, Nordgren S, Fasth S, Oresland T, Petersson K, Hulten L. The effects of age, gender, and parity on rectoanal functions in adults. Scand J Gastroenterol 1990; 25: 1247-56. [CrossRef]

4. Bozkurt MA, KocataşA, SürekA, Kankaya B, Kalaycı MU, Alış H. The importance of defecography in the assessment of the etiology of chronic constipation: An analysis of 630 patients. Ulusal Cer Derg 2014; 30: 183-5.

5. Devanarayana NM, Rajindrajith S. Bowel habits and behaviors related to defecation in 10- to 16-year olds: Impact of socioeconomic characteristics and emotional stress. J Pediatr Gastroenterol Nutr 2011; 52:569-73. [CrossRef]

6. Nehra V, Bruce BK, Rath-Harvey DM, Pemberton JH, Camilleri M. Psychological disorders in patients with evacuation disorders and constipation in a tertiary practice. Am J Gastroenterol 2000; 95: 17558. [CrossRef]

7. Masand PS, Keuthen NJ, Gupta S, VirkS, Yu-Siao B, Kaplan D. Prevalence of irritable bowel syndrome in obsessive-compulsive disorder. CNS Spectr 2006; 11:21-5. [CrossRef]

8. BennettEJ, Piesse C, Palmer K, Badcock CA, Tennant CC, Kellw JE. Functional gastrointestinal disorders: psychological, social, and somatic features. Gut 1998; 42: 414-20. [CrossRef]

9. Schmitt BD. Toilet training refusal: avoid the battle and win the war. Contemp Pediatr 1987; 4: 32-50.

10. Longstreth GF, Thompson WG, Chey WD, Houghton LA, Mearin F, Spiller RC. Functional bowel disorders. Gastroenterology 2006; 130: 1480-91. [CrossRef]

11. Taymur I, Turkçapar MH, Örsel S, Sargın E, Akkoyunlu S. Validity and reliability of the Turkish version of the personality belief questionnaireshort form (PBQ-STF) in the university students. Klinik Psiyatri 2011; 14: 199-209.

12. Zigmond AS, Snaith RP. The hospital anxiety and depression scale. Acta Psychiatr Scand 1983; 67:361-70. [CrossRef]

13. Aydemir Ö, Güvenir T, Küey L, Kültür S. Hastane anksiyete ve depresyon ölçeği Türkçe formunun geçerlik güvenilirlik çalışması. Türk Psikiyatri Dergisi 1997; 8: 280-7.

14. Obsessive Compulsive Cognition Working Group. Psychometric validation of the obsessive belief questionnaire and interpretation of intrusions inverntory-Part 2: factor analysis and testing of a briefversion. Behav Res Ther 2005; 43: 1527-42. [CrossRef]

15. Boysan M, Beşiroğlu L, Çetinkaya N. Obsesif inanışlar ölçeği-44'ün (OIÖ-44) Türkçe formunun geçerlilik ve güvenirliği. Nöropsikiyatri Arşivi 2010; 47: 216-22.

16. Bharucha AE, Pemberton JH, Locke GR 3rd. American gastroenterological association medical position statement on constipation. Gastroenterology 2013; 144:211-7. [CrossRef] 
17. Dennison C, Prasad M, Lloyd A, Bhattacharyya SK, Dhawan R, Coyne $K$. The health-related quality of life and economic burden of constipation. Pharmacoeconomics 2005; 23: 461-76. [CrossRef]

18. Öztürk MO, Uluşahin A. Kişilik bozuklukları. Kişilik Bozuklukları In: Öztürk MO, editor. Ruh sağlığı ve Bozukluklar, 8th edn. Nobel Medical Publication; 2008: 427-42.

19. Cao A, Chintamani KK, Pandya AK, Ellis RD. NASA TLX: software for assessing subjective mental workload. Behav Res Methods 2009; 41: 113-7. [CrossRef]

20. Klauser AG, Voderholzer WA, Heinrich CA, SchindlbeckNE, Müller-Lissner SA. Behavioural modification of colonic function. Can constipation be learned? Dig Dis Sci 1990; 35: 1271-5. [CrossRef]

21. Whitehead WE. Constipation-. Constipation In: Kamn \& JE LennardJones editors. IIIness behaviour. Wrightson Biomedical Publishing LTD Petersfield UK; 1994: 95-100.

22. Rao SS, Tuteja AK, Vellema T, KempfJ, Stessman M. Dyssynergic defecation: demographics, symptoms, stool patterns and quality of life. J Clin Gastroenterol 2004; 38: 680-5. [CrossRef]
23. Oztürk R, S S. Defecation disorders: an important subgroup of functional constipation, its pathophysşiology, evaluation and treatment with biofeedback. Turk J Gastroenterol 2007; 18: 139-49. [CrossRef]

24. Chan AO, Cheng C, Hui WM, Hu WH, Wong NY, Wong WM, et al. Differing coping mechanisms, stres level and anorectal physiology in patients with functional constipation. Wolrd J Gastroenterol 2005; 11: 5362-6. [CrossRef]

25. Ozokutan BH, Zoroglu S, Ceylan H, Ozkan KU. Psychological evaluation of children with idiopathic constipation and their parents. Pediatr Int 2005; 47: 311-5. [CrossRef]

26. Tam YH, Li AM, So HK, Shit KY, Pang KK, Wong YS, et al. Socioenvironment factors associated with constipation in Hong Kong children and Rome III criteria. J Pediatr Gastroenterol Nutr 2012; 55: 56-61. [CrossRef]

27. Jodorkovsky D, Dunbar KB, Gearhart SL, Stein EM, Clarke JO. Biofeedback therapy for defecatory dysfunction: "real life" experience. J Clin Gastroenterol 2013; 47: 252-5. [CrossRef]

\section{ORIJINAL ÇALIŞMA-ÖZET}

Turk J Surg 2019; 35 (3): 165-170

\section{Fonksiyonel kabızlık ve tutucu-anal kişilik özellikleri arasındaki ilişki}

Tonguç Utku Yılmaz ${ }^{1}$, Halil İbrahim Taş $^{2}$, Ezgi Uçarr ${ }^{1}$, Cem Cerit ${ }^{3}$, Altay Çelebi ${ }^{4}$, Sertaç Ata Güler ${ }^{1}$, Zafer Utkan ${ }^{1}$

${ }^{1}$ Kocaeli Üniversitesi Tıp Fakültesi, Genel Cerrahi Anabilim Dalı, Kocaeli, Türkiye

${ }^{2}$ Çanakkale 18 Mart Üniversitesi Tıp Fakültesi, Psikiyatri Anabilim Dalı, Çanakkale, Türkiye

${ }^{3}$ Kocaeli Üniversitesi Tıp Fakültesi, Psikiyatri Anabilim Dalı, Kocaeli, Türkiye

${ }^{4}$ Kocaeli Üniversitesi Tıp Fakültesi, Gastroenteroloji Bilim Dalı, Kocaeli, Türkiye

\section{ÖZET}

Giriş ve Amaç: Kabızlık çok sık görülen bir defekasyon problemi olup çeşitli çevresel faktörlerle ilişkilidir. Defekasyon, anal dönem kişilik bulgularının oluştuğu çocukluk anal dönemde görülür. Çocukluk anal dönemdeki problemler sadece kişilik özelliklerini değil defekasyon fonksiyonlarını da etkileyebilir. Bu çalışmada fonksiyonel kabızlığı olan hastalarda kabızlık ve anal kişilik bozukluğu arasındaki ilişki incelenmesi amaçlanmıştır.

Gereç ve Yöntem: Çalışmaya ROME III kriterlerine göre fonksiyonel kabızlığı olan hastalar dahil edildi. İrritabl bağırsak hastalığı, yavaş geçişli konstipasyonu, çıkış obstrüksiyonu olan, malignitesi olan, psikiyatrik hastalığı olan hastalar çalışma dışı bırakıldı. Hastalar kişilik inanç, hastane anksiyete, depresyon ve obsesif inanç anketi doldurdu. Konstipe hastalar benign anorektal hastalığı olan ve olmayan olarak iki gruba ayrıldı. Elde edilen bulgular sağlıklı gönüllülerle karşılaştırıldı.

Bulgular: Fonksiyonel kabızlığı olan 47 hasta çalışmaya dahil edilmiştir. Çekingen, obsesif kompulsif, antisosyal, narsist, paranoid kişilik inançları kabız ve hastalıklı hastalarda kontrol grubuna göre daha fazla bulunmuştur. Mükemmelliyetçilik, önem, kontrol ve hastane anksiyetesi kabız ve hastalıklı grupta kontrol grubuna göre daha fazla bulunmuştur.

Sonuç: Kabızlık sosyoekonomik, duygusal stres, yaş ve diyet gibi çeşitli faktörlerden etkilenir. Bu çalışmada fonksiyonel kabızlığı olan hastalarda tutucu anal kişilik özelliklerinin daha belirgin olduğunu bulduk. Biofeedback bir çeşit defekasyon kontrol psikoterapisi olduğundan tedavide kullanılabilir.

Anahtar Kelimeler: Kabızlık, anal, çocukluk, kişilik bozukluğu, biofeedback

Doi: 10.5578/turkjsurg.4035 